\title{
A. Gritsenko Dynamic Control of the Engine Output \\ Doctor \\ Environmental Control and Test Parameters
}

South Ural State University Automobile and Tractor Faculty Russia

South Ural State Agrarian University Russia

V. Shepelev Ph. D

South Ural State University Automobile and Tractor Faculty Russia SILKWAY International University Kazakhstan

\section{G. Salimonenko}

Ph. D.student South Ural State University Automobile and Tractor Faculty

Russia

Yu. Cherkassov

Ph. D

Kostanay Engineering and

Economics University

Named after M. Dulatov

Kazakhstan

P. Buyvol

Kazan Federal University

Transport Systems Service Department

Russia

In modern transport, environmental control plays a key role in shaping the strategy for managing the technical condition of nodes and systems. The first step in reducing the toxicity of exhaust gas emissions was the introduction of EURO standards, successively from EURO-0 to EURO-6. Accompanying the appearance of EURO standards, exhaust systems were supplemented with catalytic converters, which deactivated most of the harmful emissions. Oxygen sensors also began to play a key role, the installation of which resulted in the appearance of feedback. Thus, the global automotive industry is closer to the controllability of the engine output parameters. However, there are not enough parameters, operating modes, and additional controls available for this purpose. The presented studies used a new method of selective control of exhaust gases in each cylinder. The following parameters were used for monitoring: the crankshaft speed, complete and partial (cycle-by-cycle) disconnection of cylinders, $\mathrm{O}_{2}, \mathrm{CO}, \mathrm{CO}_{2}$, and $\mathrm{CH}$. The mode was provided by the number of the engine's disconnected operated cycles and the crankshaft speed. The control was performed by the internal adjustment of the fuel supply under the influence on the injection duration of the electromagnetic nozzle. During the research, we established the minimum values of the exhaust toxicity parameters during the test effects. This method with a combination of modes and parameters allows us to reduce the toxicity of exhaust gases and to improve the efficiency and effectiveness of vehicles.

Keywords: ecology, efficiency, internal combustion engine, diagnostics.

\section{INTRODUCTION}

One of the main tasks of modern engine building is to improve the operational and environmental performance of internal combustion engines (ICEs) [1-7]. Due to the increased number of motor vehicles, the share of oil fuel consumption is constantly growing. Along with the increasing number of electric vehicles, ICEs are still the basis of the world transport fleet [8]. Until a complete transition to electric transport, considerable attention should be paid to monitoring the environmental parameters of ICEs [9-11].

Along with the development of fundamentally new ICE models, which require complex long-term studies and significant capital investments, it is essential to improve the existing ICEs and their diagnosing methods [12].

The main works of the leading scientists in the field of transport ecology are aimed at the development of new devices for the neutralization of exhaust emissions, systems for monitoring the parameters of exhaust toxicity, as well as selective adjustment of fuel supply when the technical condition of ICE systems changes [13-16]. The effectiveness of these solutions has been

Received: April 2020, Accepted: June 2020

Correspondence to: Ph.D Vladimir Shepelev

South Ural State University, Automobile and Tractor

Faculty, Lenin Avenue 76, 454080 Chelyabinsk, Russia

E-mail: shepelevvd@susu.ru

doi:10.5937/fme2004889G

(C) Faculty of Mechanical Engineering, Belgrade. All rights reserved proven during the operation of completely new vehicle systems having no running time [17-20]. Ideal conditions for the operation of vehicles were in these studies. However, the realities of operation show that, in most cases, car owners, car fleets, and automobile enterprises are unable to provide ideal conditions for the operation and maintenance of vehicles [21-24]. The high complexity of troubleshooting in the main ICE systems affecting the environmental performance of vehicles also encourages the development of new troubleshooting methods to maintain the highest environmental vehicle class [25-28].

Thus, the purpose of the study is to increase the reliability of diagnosing ICEs by supplementing the composition of the measured parameters with the results of studying exhaust gases of individual cylinders in test modes [29].

\section{THEORETICAL RESEARCH}

The lack of diagnostic tools that reliably determine the factors affecting the environmental performance of ICEs leads to high costs for detecting the troubleshooting (about $3000 \ldots 7000$ troubles per car). Based on the analysis of the existing methods for assessing the factors affecting the environmental performance of ICEs and the wear of the main ICE systems, we can conclude that such elements as the cylinder-piston group (CPG) are a rather reliable system, and the $\mathrm{CPG}$ wear factor can be neglected. However, at the same time, we should have a 
way to control the technical condition of the CPG, preferably integrated into the ICE control system to be able to control the CPG at any time. An analysis of ICE element failures shows that the maximum number of them falls at electromagnetic nozzles, spark plugs, and the exhaust catalytic converter. Besides, these elements significantly affect the environmental performance of ICEs [30-32].

Given the aforesaid and according to the set purpose, we identified the following research tasks.

1. To identify the relationship between the technical condition of ICE elements and the toxicity parameters.

2. To develop a method for assessing the technical condition of electromagnetic nozzles, spark plugs, and exhaust catalytic converters by the toxicity parameters during selective exhaust gas sampling.

3. To develop diagnostic equipment and experimentally establish diagnostic test modes and control parameters to study the technical condition of ICE systems.

4. To justify the diagnostic method using the developed equipment, carry out comparative studies and show their effectiveness.

\section{RESEARCH PROCEDURE}

In the course of the experimental studies, the input parameters are: 1) the spark gap of the spark plug; 2) the change in the capacity of the electromagnetic nozzle; 3 ) the resistance of the catalytic converter. The controlled parameters include the temperature of the ICE coolant, the technical condition of the cylinder-piston group (CPG), the gas distribution mechanism (GDM), the oil temperature. The output parameters include the ICE crankshaft, $\mathrm{CO}, \mathrm{CO}_{2}, \mathrm{CH}, \mathrm{O}_{2}$. After that, the data was processed in the SigmaPlot software suite, the verification and comparative studies were carried out with the use of Excel and Mathcad.

As we can see from the graph in Fig. 1, the nature of the change in the concentration of $\mathrm{CO}_{2}$ and $\mathrm{NO}_{\mathrm{x}}$ in the exhaust gases is rather similar. When the engine operates in the rich mixture zone at $\alpha=0.55 \ldots 0.9$, the concentration of $\mathrm{CO}_{2}$ increases almost linearly from 4 to more than $11 \%$. At the same time, the concentration of $N O_{\mathrm{x}}$ in the same range increases from 0 to $0.42 \%$. The law of the change in the concentration of $N O_{x}$ can be almost taken as linear in this section. Next, we can see from Fig. 1 the maximum concentration of $\mathrm{CO}_{2}$ and $N O_{\mathrm{x}}$ actually coinciding at $\alpha=1.02 \ldots 1.05$.

Then, at $\alpha>1.05 \ldots 1.10$ the formation of $N O_{\mathrm{x}}$ decreases, which is connected with a decrease in the combustion temperature. The nature of the change in $\mathrm{CO}_{2}$ and $\mathrm{NO}_{\mathrm{x}}$ also remains the same in this range. Thus, we can indirectly judge on the value of $N O_{\mathrm{x}}$ by the value of the concentration of $\mathrm{CO}_{2}$, with a good approximation. Notably, the given research material did not set the task to determine the dependence of $N O_{\mathrm{x}}$, but in our future work we will use a gas analyzer enabling to measure $N O_{\mathrm{x}}$.

To study the relationship between the spark gap of the spark plug and the ionization voltage, we studied this process. To this end, we artificially set the gaps of $0.5,0.7$ and $1.4 \mathrm{~mm}$. At the same time, the air density in the chamber of the test device changed from 7 to 20 $\mathrm{kg} / \mathrm{m}^{3}$. After that, we monitored the change in the increment of the secondary voltage $d U 2 / d t$, V/s (Fig. 2).

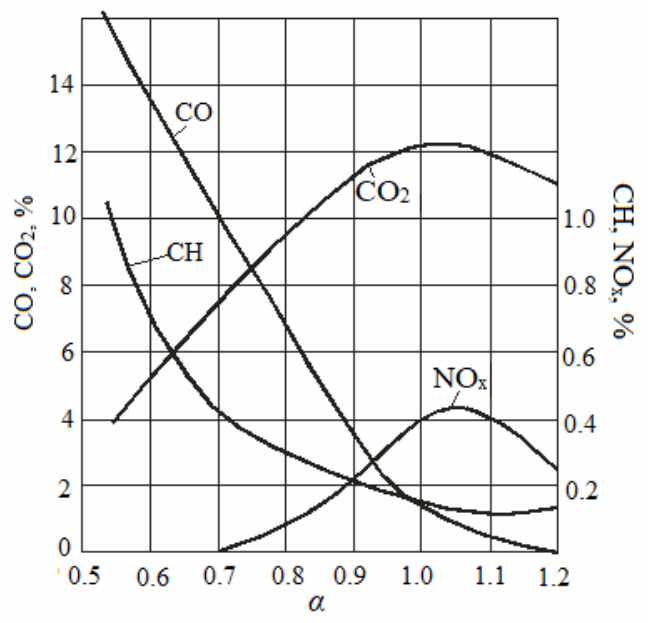

Figure 1. A dependence of the concentration of $\mathrm{CO}, \mathrm{CH}$, $\mathrm{CO}_{2}$ and $\mathrm{NO}_{\mathrm{X}}$ on $\alpha$

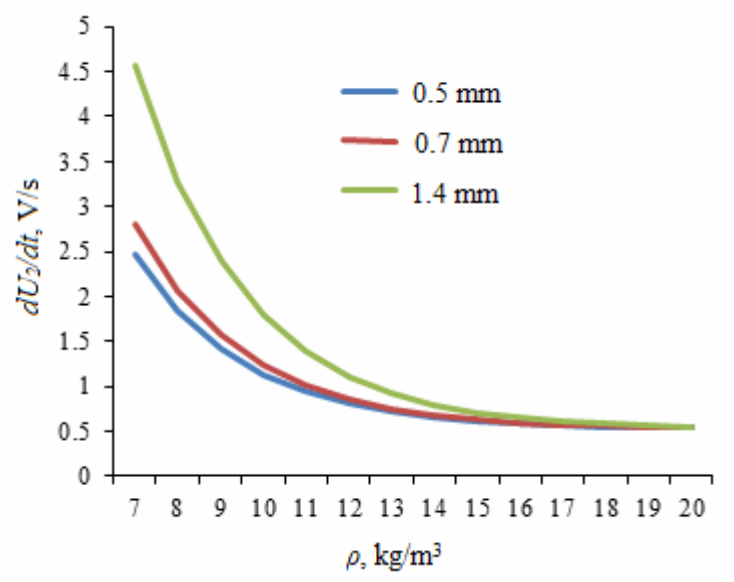

Figure 2. The dependence of the increment of the secondary voltage $d U 2 / d t(\mathrm{~V} / \mathrm{s})$ on the air density in the chamber of the test device $\rho\left(\mathrm{kg} / \mathrm{m}^{3}\right)$ for various gaps in the spark plug

As we can see from Fig. 2, when installing the spark plug with a maximum gap of $1.4 \mathrm{~mm}$, the change in the secondary voltage reaches its maximum values.

A generalized analysis of the data shown in Fig. 2 allowed us to establish the relationship in the form of equations:

$$
\begin{gathered}
\delta_{S P}=0.526+\exp \left(2.951+0.822 \frac{d U_{2}}{d t}-0.386 \cdot \rho\right) \\
\delta_{S P}=0.545+\exp \left(2.937+0.475 \frac{d U_{2}}{d t}-0.330 \cdot \rho\right)(2)
\end{gathered}
$$

where $\delta_{\mathrm{SP}}$ is an interelectrode gap of the spark plug, $\mathrm{mm} ; d U 2 / d t$ is the growth rate of the secondary voltage, $\mathrm{kV} / \mu \mathrm{s} ; \rho$ is the air density in the plug gap, $\mathrm{kg} / \mathrm{m}^{3}$.

The presented Eqs. (1-2) link the increment of the ionization voltage and the air density in the chamber of the test device with the breakdown gap of the spark plugs.

So, for example, at an interelectrode gap of $0.9 \mathrm{~mm}$, the breakdown voltage $U_{b r}(\mathrm{kV})$ will be higher for a smaller change in the secondary voltage $d U 2 / d t(\mathrm{~V} / \mathrm{s})$ (Fig. 3). 


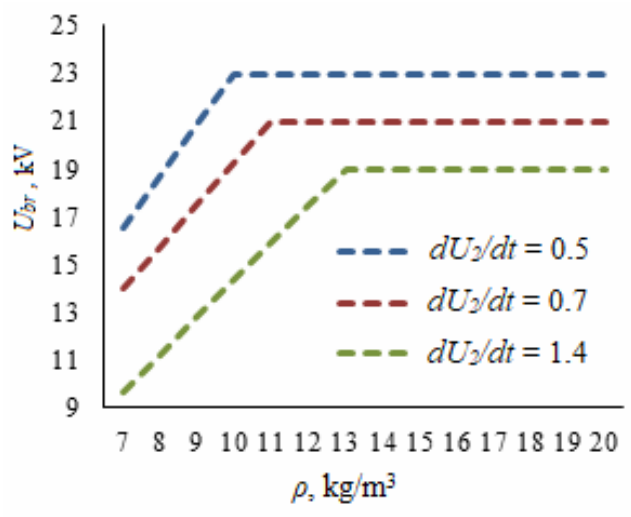

Figure 3. The dependence of the breakdown voltage $U_{b r}$ $(\mathrm{kV})$ on the air density in the chamber of the test device $\rho$ $\left(\mathrm{kg} / \mathrm{m}^{3}\right)$ at various values of the secondary voltage increment $d U_{2} / d t(\mathrm{~V} / \mathrm{s})$

The analytical studies allowed us to establish that the limit value of the spark plug gap is a gap of $1.1 \mathrm{~mm}$ upwards and $0.3 \mathrm{~mm}$ downwards.

A joint analysis of the preliminary experiments on studying the relationship between the spark gap of the spark plug, the change in the capacity of the electromagnetic nozzle, and the resistance of the catalytic converter with the exhaust toxicity parameters showed their significant relationship. These studies allowed us to create a generalized mathematical model taking into account the composition of the exhaust gases to the catalytic converter with the technical condition of the spark plugs, electromagnetic nozzles, and the catalytic converter. All research results were summarized in a series of functional dependencies:

$$
\begin{gathered}
n=f(Z, F, R) . \\
O_{2}=f(Z, F, R) . \\
C H=f(Z, F, R) . \\
C O=f(Z, F, R) . \\
C_{2}=f(Z, F, R) .
\end{gathered}
$$

where $n$ is the crankshaft speed of the internal combustion engine, rpm; $\mathrm{O}_{2}$ is the oxygen content in the exhaust gases, \%; $\mathrm{CH}$ is the hydrocarbon content, ppm; $\mathrm{CO}$ is the carbon monoxide content, $\% ; \mathrm{CO}_{2}$ is the carbon dioxide content in the exhaust gases, $\% ; Z$ is the spark plug gap, mm; $F$ is the capacity of the electromagnetic nozzle, $\% ; R$ is the equivalent resistance of the converter, $\mathrm{mm}$.

The data was processed using the MatlabSimulink software suite. The calculation model is presented in Fig. 4.

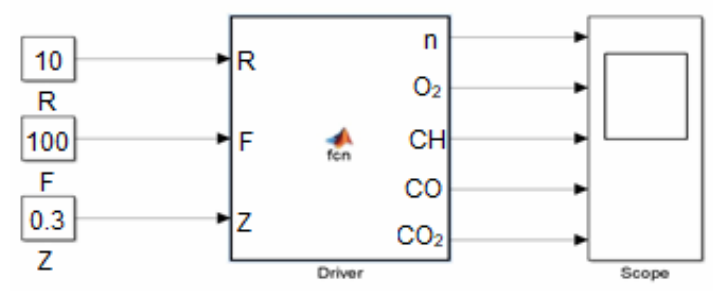

Figure 4. The calculation model in the MatlabSimulink software suite
When processing the data in the MatlabSimulink software, we obtained the dependencies of various output parameters on the combination of three input parameters. So, Fig. 5 and Fig. 6 present the dependence of the concentration of $\mathrm{CO}_{2}(\%)$ in the exhaust gases on the equivalent resistance of the catalytic converter $R$ $(\mathrm{mm})$, the capacity of the electromagnetic nozzle $F(\%)$, and the spark plug gap $Z(\mathrm{~mm})$.

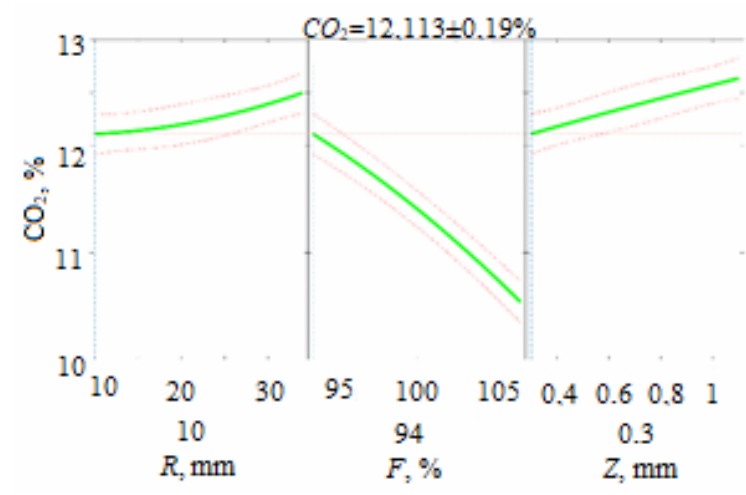

Figure 5. The dependence of the concentration of $\mathrm{CO}_{2}(\%)$ in the exhaust gases on the equivalent resistance of the catalytic converter $R=10 \mathrm{~mm}$, the capacity of the electromagnetic nozzle $F=94 \%$ and the spark plug gap $Z=0.3 \mathrm{~mm}$.

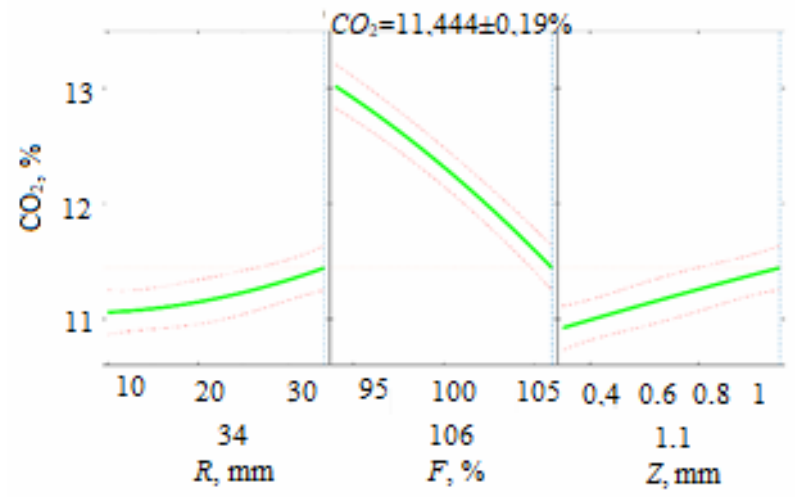

Figure 6. The dependence of the concentration of $\mathrm{CO}_{2}(\%)$ in the exhaust gases on the equivalent resistance of the catalytic converter $R=34 \mathrm{~mm}$, the capacity of the electromagnetic nozzle $F=106 \%$ and the spark plug gap $Z=1.1 \mathrm{~mm}$.

We can see from Fig. 5 and Fig. 6 that the concentration of $\mathrm{CO}_{2}$ increases with a decrease in the equivalent resistance of the catalytic converter from 10 to $34 \mathrm{~mm}$ in the catalytic converter. The concentration of $\mathrm{CO}_{2}$ decreases sharply with an increase in the capacity of the electromagnetic nozzles from 94 to $106 \%$. The concentration of $\mathrm{CO}_{2}$ increases with an increase in the spark plug gap from 0.3 to $1.1 \mathrm{~mm}$.

A failure analysis of automotive catalytic converters shows that when their cross-section is reduced, cleaning of the working cylinders is significantly impaired. This causes the accumulation of exhaust gases and their return into the combustion chamber through the exhaust system, which results in an increased content of $C O$, $\mathrm{CH}$, interrupted the mixture ignition, excessive fuel consumption, and a significant power loss. An increase in the capacity of the electromagnetic nozzles causes an over-enrichment of the fuel and, as a consequence, worsened fuel combustion and an increase in $C O$ and 
$\mathrm{CH}$ emissions. A decrease in the capacity of the nozzles leads to excessive depletion of the mixture and an increase in $\mathrm{NO}$ and $\mathrm{CO}_{2}$. The increase in the crosssection of the spark plug gap leads to an increase in the power of the spark in the gap, but it simultaneously complicates the mixture ignition. Then, $N O$ increases sharply. At the same time, a reduced spark plug gap leads to the appearance of a weak spark unable to ignite the mixture, which causes a sharp increase in $\mathrm{CH}$.

We similarly built the dependences of the concentration of $\mathrm{CO}, \mathrm{CH}, \mathrm{O}_{2}$ in exhaust gases on the equivalent resistance of the catalytic converter $R$ the capacity of the electromagnetic nozzle $F$ and the spark plug gap $Z$.

Let us analyse the change in the ICE crankshaft speed $n$ (rpm) on the equivalent resistance of the catalytic converter $R$, the capacity of the electromagnetic nozzle $F$, and the spark plug gap $Z$ (Fig. 7. and Fig. 8).

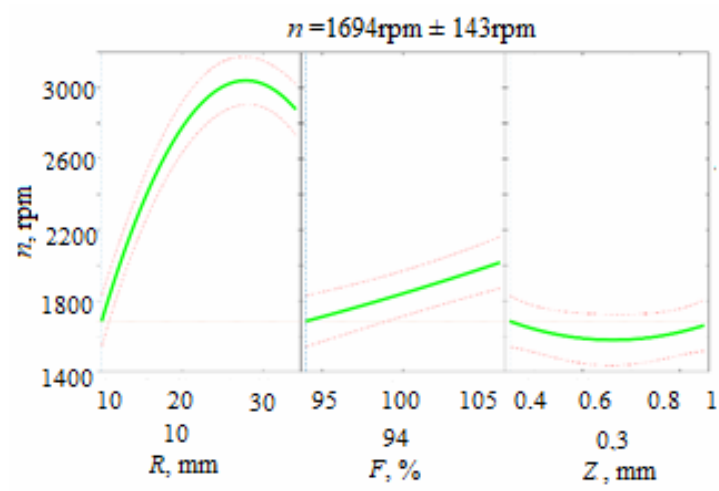

Figure 7. The dependence of the ICE crankshaft speed $\boldsymbol{n}$ on the equivalent resistance of the catalytic converter $R=10$ $\mathrm{mm}$, the capacity of the electromagnetic nozzle $F=94 \%$, and the spark plug gap $Z=0.3 \mathrm{~mm}$.

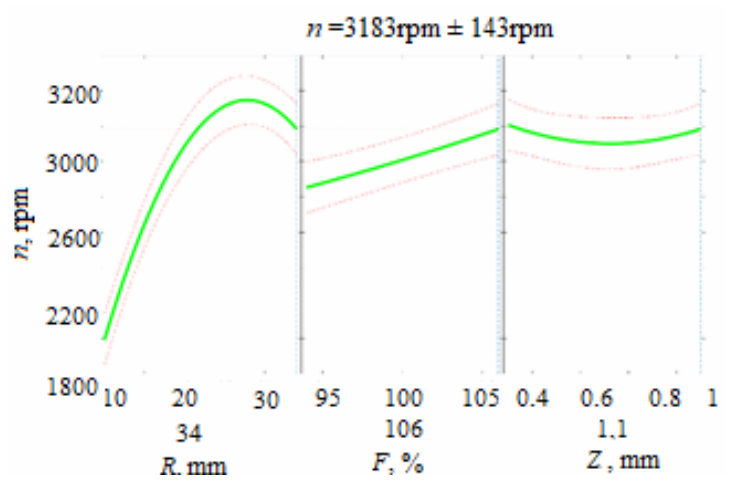

Figure 8. The dependence of the ICE crankshaft speed $n$ on the equivalent resistance of the catalytic converter $R=34$ $\mathrm{mm}$, the capacity of the electromagnetic nozzle $F=106 \%$, and the spark plug gap $Z=1.1 \mathrm{~mm}$.

We can see from Fig. 7 and Fig. 8 that the ICE crankshaft speed sharply increases with a decrease in the equivalent resistance of the catalytic converter from 10 to $34 \mathrm{~mm}$. The ICE crankshaft speed increases with an increase in the capacity of the electromagnetic nozzles from 94 to $106 \%$. The speed decreases in the interval of the change in the spark plug gap of 0.3-0.7 mm. It grows when the gap changes from 0.7 to $1.1 \mathrm{~mm}$.

\section{THE HEAT CALCULATION OF THE STUDIED ICE}

Let us make a heat calculation to analyse the composition of the exhaust gases. Let us choose the source data for the calculation. It is well known that our experimental setup based on the ICE of a VAZ-2112 car has a compression ratio of $\varepsilon=11$. During the experiments, we used A-92 gasoline. Besides, the average elemental composition and molecular weight of A-92 gasoline was: carbon $C=0.855$; hydrogen $H=0.145$; molecular weight $m_{T}=115 \mathrm{~kg} / \mathrm{kmol}$. The lower heating value of A-92 gasoline can be calculated by Eq. (8):

$$
H_{u}=33.91 C+125.60 H-10.89(O-S)-2.51(9 H+W) .
$$

The theoretical amount of air needed to combust 1 $\mathrm{kg}$ of fuel is determined by Eq. (9-10):

$$
\begin{gathered}
L_{0}=\frac{1}{0.208}\left(\frac{C}{12}+\frac{H}{4}+\frac{S}{32}-\frac{O}{32}\right) . \\
l_{0}=\frac{1}{0.23}\left(\frac{8}{3} C+8 H-O\right) .
\end{gathered}
$$

The excess air ratio is determined based on the following considerations. An injection engine power supply system is installed on modern engines, [30, 31, 32]. The usability of the injection supply system for the designed engine allows us to obtain, provided that an appropriate adjustment is used, both the power and the economic mixture $\alpha=0.7 \ldots 1.3$ according to the assignment.

The amount of the combustible mixture at $\alpha=0.95$ is determined by Eq. (11):

$$
M_{1}=\alpha \cdot L_{0}+\frac{1}{m_{T}} .
$$

The number of individual components of complete combustion products at $K=0.5$ and the adopted speed mode:

$$
\begin{gathered}
M_{\mathrm{CO}_{2}}=\frac{C}{12}+2\left(\frac{1-\alpha}{1+K}\right) \cdot 0.208 \cdot L_{0} . \\
M_{\mathrm{CO}}=2\left(\frac{1-\alpha}{1+K}\right) \cdot 0.208 \cdot L_{0} . \\
M_{\mathrm{H}_{2} \mathrm{O}}=\frac{H}{12}-2 \cdot K\left(\frac{1-\alpha}{1+K}\right) \cdot 0.208 \cdot L_{0} . \\
M_{\mathrm{H}_{2}}=2 \cdot K\left(\frac{1-\alpha}{1+K}\right) \cdot 0.208 \cdot L_{0} . \\
M_{N_{2}}=0.792 \cdot \alpha \cdot L_{0} \cdot \\
M_{2}=M_{\mathrm{CO}_{2}}+M_{C O}+M_{H_{2} O}+M_{H_{2}}+M_{N_{2}} .
\end{gathered}
$$

Since the excess air ratio for the desired ICE varies within 0.7-1.3, substituting these values with an increment of 0.05 into Eqs. (12-17), we obtain the following dependencies (Fig. 9).

We can see from the analysis of Fig.9 that with an increase in the excess air ratio $\alpha$, the consumption of the combustible mixture increases, and the emissions of $\mathrm{CO}_{2}$ and $\mathrm{H}_{2} \mathrm{O}$ increase slightly. The emissions of $\mathrm{NO}_{\mathrm{x}}$ also increase due to a larger amount of free oxygen and an increased fuel combustion temperature, which results in the increase in the amount of molecular oxygen. 


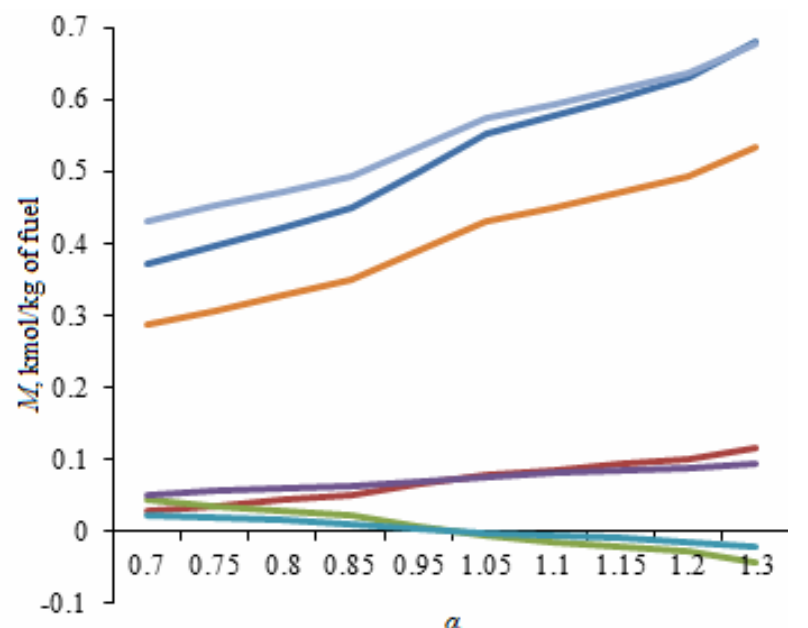

$\alpha$

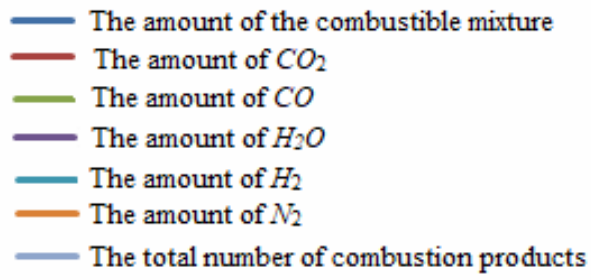

Figure 9. The dependence of the number of individual components of complete combustion products $M$ on the excess air ratio $\alpha$

Here, we presented a generalized calculation of the largest possible number of components of exhaust gases based on the main, well-known models from the course of ICE calculation and combustion process chemistry. Although in the next work, the concentration of $\mathrm{NO}_{\mathrm{x}}$ is controlled indirectly by the content of $\mathrm{CO}_{2}$. As we can see from Fig. 9, in the rich mixture zone at $\alpha=0.7 \ldots 0.9$, we should steadily increase the amount of the combustible mixture to maintain the combustion process, while it can be seen that the total number of complete combustion products and the amount of $N_{2}$ sharply increase. In the poor mixture zone at $\alpha>1.05 \ldots 1.30$, these parameters grow with the same dynamics. At the same time, the dynamics of an increasing concentration of $\mathrm{CO}_{2}$ and $\mathrm{H}_{2} \mathrm{O}$ is very low throughout the change in the excess air ratio $\alpha$. Meanwhile, in the rich mixture zone at $\alpha=0.7 \ldots 0.9$, the amount of $\mathrm{H}_{2}$ and $\mathrm{CO}$ changes insignificantly. In the poor mixture zone at $\alpha>$ $1.05 \ldots 1.30$, the amount of $\mathrm{H}_{2}$ and $\mathrm{CO}$ decreases dynamically. This is explained by better combustion completeness.

\section{CHOOSING THE RESEARCH METHODOLOGY}

We developed a research methodology to carry out all the planned complex works. It included the following steps: 1. To select the necessary experimental setup; 2 . To select the necessary equipment and additional control devices; 3. To select diagnostic modes and diagnostic parameters. We opted for the VAZ-2112 ICE as the most common in the Russian Federation. The experimental setup and additional devices are shown in Fig. 10 and Fig. 11.

Besides, we selected the following main equipment: DBD-4 gasoline engine loader and INFRAKARM2.01 4-component gas analyser. Additional control devices were needed to control the secondary parameters of the
ICE systems [17, 18]. The additional control devices include a MT-10 motor tester and a PC.

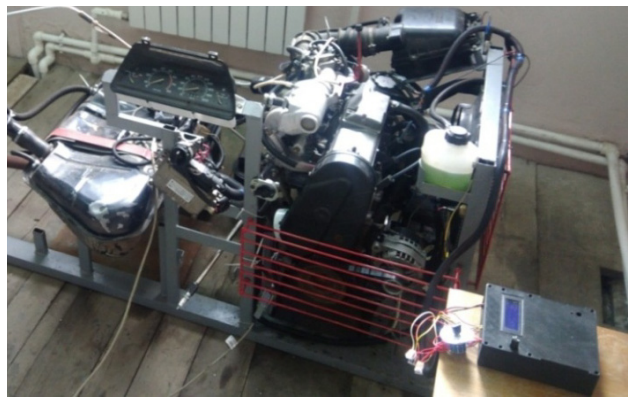

Figure 10. Experimental setup.

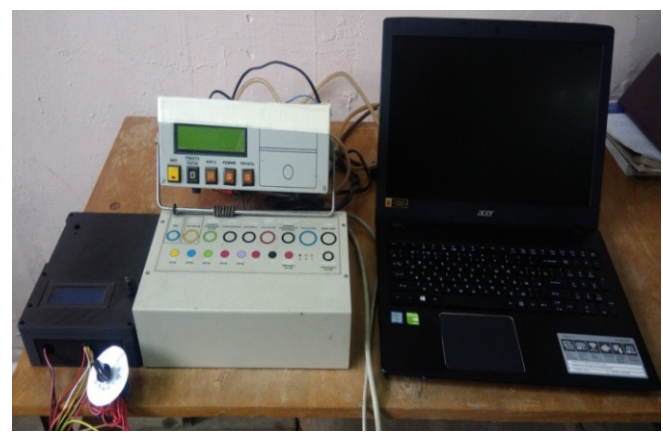

Figure 11. Equipment and additional control devices.

In the exhaust system, exhaust gas intake points are shown in individual exhaust manifolds. Holes were drilled at these points and nuts with adapters were installed to connect the gas analyser probe to them. Notably, this connection is made through a cooling coil to cool the exhaust gas before the gas analyser [33, 34, 35].

A $\lambda$-probe is shown further along the exhaust system. The catalytic converter and silencer come next. Special washers are installed at the end of the silencer to generate artificial resistance. The wires of the DBD-4 device are connected to the gap of the electromagnetic nozzles. DBD-4 is also connected to the control unit (ECU) of the ICE.

\section{THE RESULTS OF THE EXPERIMENTAL STUDIES}

Further tests were focused on comparing different exhaust gas intake options. To this end, we used an experimental setup based on the VAZ-2112 ICE (Fig. 10). The concentrations of $\mathrm{CO}, \mathrm{CH}, \mathrm{CO}_{2}$, and $\mathrm{O}_{2}$ were measured in three different ways: 1 ) the operation of the 1st cylinder and the exhaust gas intake in the common exhaust pipe; 2) the operation of all the four cylinders and the exhaust gas intake in the common exhaust pipe; 3 ) the operation of the 1 st cylinder and the exhaust gas intake in the exhaust manifold immediately after the exhaust gases leave the cylinder. The measurements were carried out with a resolution of $500 \mathrm{rpm}$, starting at $1000 \mathrm{rpm}$.

As a result, we obtained the dependence of the concentration of $C O(\%)$ in the exhaust gases on the ICE crankshaft speed $n$ (rpm) (Fig. 11). The load level when one cylinder is on corresponds to 0.25 of the rated power at nominal crankshaft speeds. All the intermediate load values were determined using a tester motor. The parameter - ICE power during testing was displayed in its standard parameters. 
As we can see from Fig. 11, during the operation of all the four cylinders and the exhaust gas intake in the common exhaust pipe, the concentration of $C O$ in the exhaust gases reaches the highest values from 9.4 to $10.2 \%$. The maximum is manifested at a point corresponding to $4,000 \mathrm{rpm}$. During the operation of the 1 st cylinder and the exhaust gas intake in the exhaust manifold, immediately after the exhaust gases leave the cylinder, the concentration of $C O$ reaches its maximum value of $4 \%$ at $1000 \mathrm{rpm}$. With an increase in the speed, the concentration of $C O$ decreases, reaching $1 \%$ at 5000 rpm. During the operation of the 1 st cylinder and the exhaust gas intake in the common exhaust pipe, the concentration of $C O$ reaches its minimum value of $1.98 \%$ at $1000 \mathrm{rpm}$. Further, the concentration of $C O$ is kept at a level of no more than $1 \%$ with an increase in the ICE crankshaft speed. However, this low $C O$ value is explained by the mixing of free air entering the outlet from neighbouring idle cylinders.

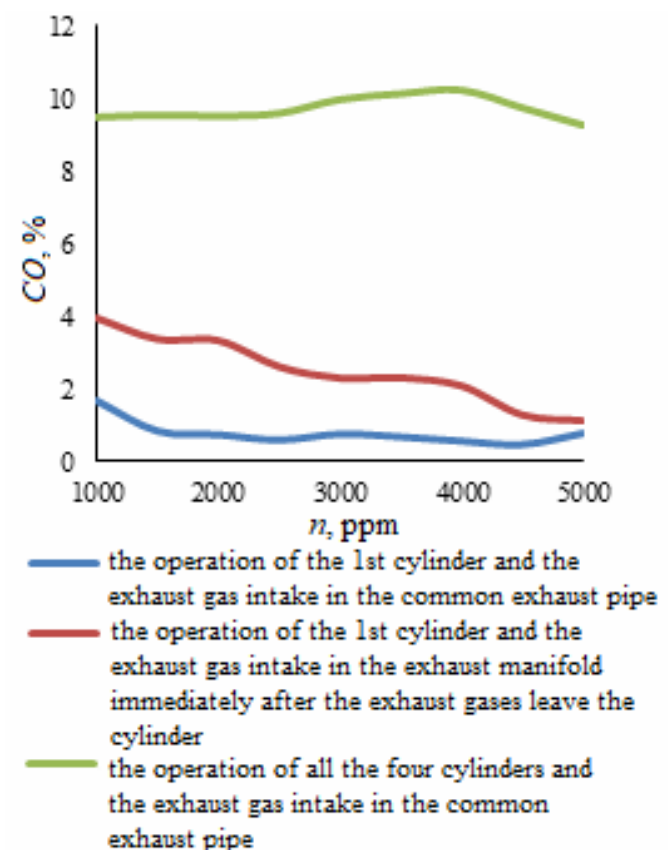

Figure 11. The dependence of the concentration of $\mathrm{CO}$ in the exhaust gases on the ICE crankshaft speed $\boldsymbol{n}$ during the operation of different cylinders

Based on the experimental data, we obtained the dependence of the concentration of $\mathrm{CH}$ (ppm) in the exhaust gases on the ICE crankshaft speed (Fig. 12).

An analysis in Fig. 12 shows that $\mathrm{CH}$ reaches significantly higher values during the operation of all the four cylinders and the exhaust gas intake in the common exhaust pipe. So at $1,000 \mathrm{rpm}$, the concentration of $\mathrm{CH}$ reaches a maximum of $715 \mathrm{ppm}$. Further, with an increase in the ICE crankshaft speed, $\mathrm{CH}$ decreases and amounts to $400 \mathrm{ppm}$ at $5000 \mathrm{rpm}$. During the operation of the 1 st cylinder and the exhaust gas intake in the common exhaust pipe and the operation of the 1st cylinder and the exhaust gas intake in the exhaust manifold immediately after the exhaust gases leave the cylinder, we observe almost identical results varying within the experimental error.

Based on the results of the experiment, we also built the dependence of the concentration of $\mathrm{CO}_{2}(\%)$ in the exhaust gases on the ICE crankshaft speed $n$ (rpm) (Fig. 13).

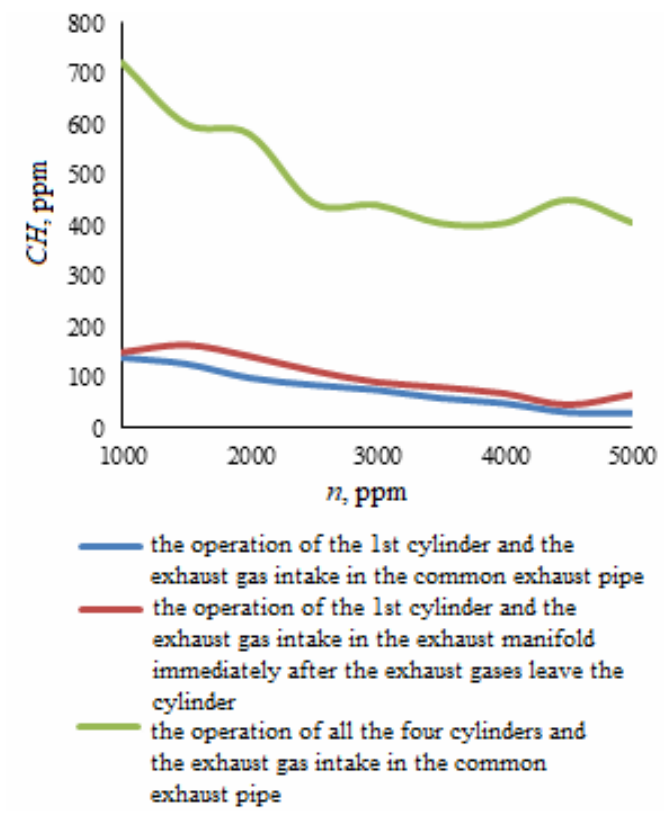

Figure 12. The dependence of the concentration of $\mathrm{CH}$ in the exhaust gases on the ICE crankshaft speed $\boldsymbol{n}$ during the operation of different cylinders

An analysis of the data in Fig. 13 shows that the highest value of the concentration of $\mathrm{CO}_{2}$ is observed during the operation of the 1 st cylinder and the exhaust gas intake in the exhaust manifold immediately after the exhaust gases leave the cylinder. So, at the ICE crankshaft speed of $1,000 \mathrm{rpm}$, the concentration of $\mathrm{CO}_{2}$ is $10.7 \%$. Then, the concentration of $\mathrm{CO}_{2}$ grows and reaches a maximum of $14 \%$ at the ICE crankshaft speed of 4,500 rpm. During the operation of all the four cylinders and the exhaust gas intake, a slightly lower $\mathrm{CO}_{2}$ value is observed in the common exhaust pipe. This is explained by free oxygen coming from the neighbouring cylinders in the absence of combustion in them. The lowest $\mathrm{CO}_{2}$ value is observed during the operation of the 1st cylinder and the exhaust gas intake in the common exhaust pipe. Free oxygen from the neighbouring cylinders also has a significant effect in the absence of combustion in them.
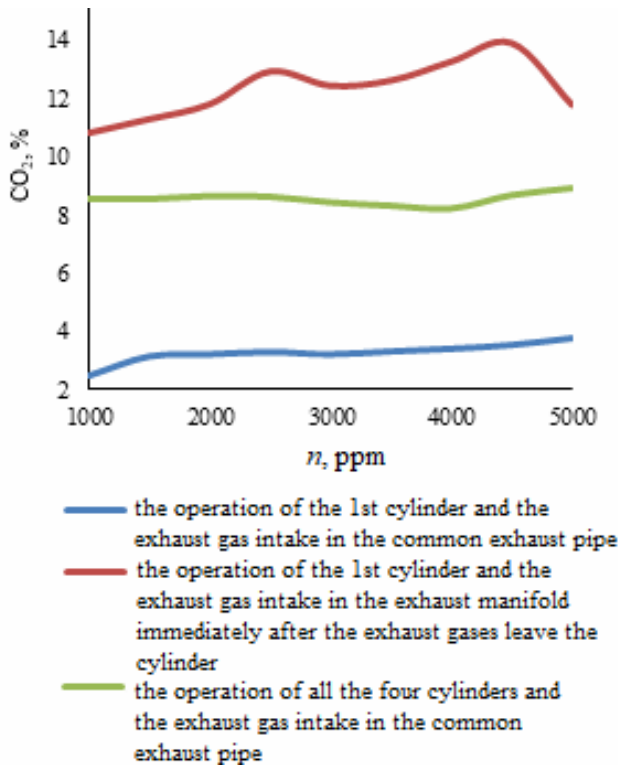

Figure 13. The dependence of the concentration of $\mathrm{CO}_{2}$ in the exhaust gases on the ICE crankshaft speed $n$ during the operation of different cylinders 
Based on the results of the experiment, we built the dependence of the concentration of $\mathrm{O}_{2}(\%)$ in the exhaust gases on the ICE crankshaft speed $n$ (rpm) (Fig. 14).

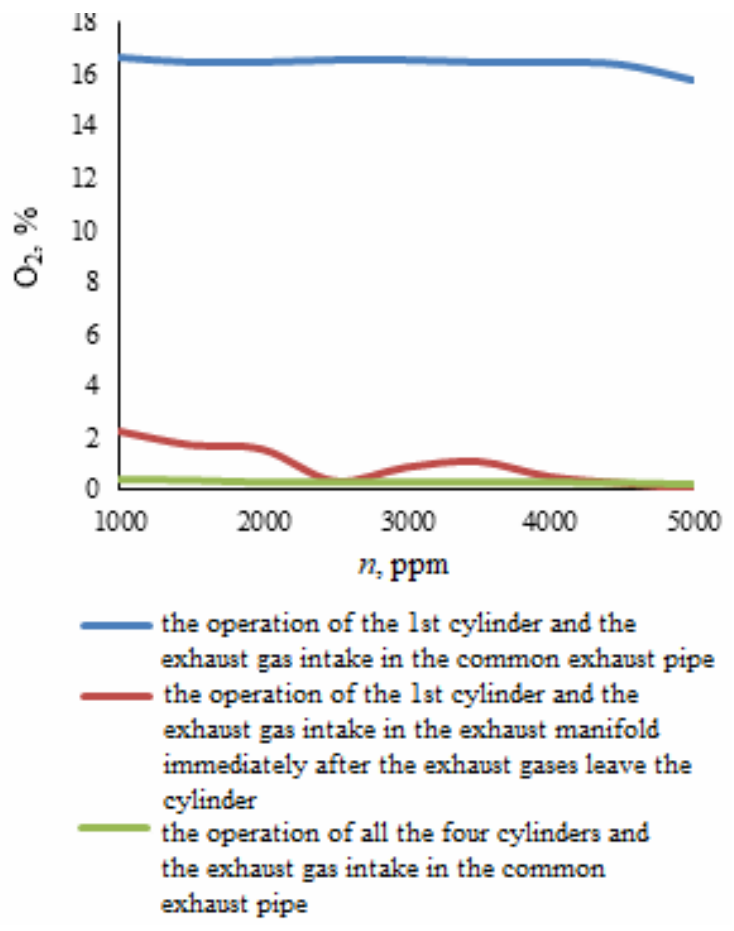

Figure 14. The dependence of the concentration of $\mathrm{O}_{2}$ in the exhaust gases on the ICE crankshaft speed $\boldsymbol{n}$ during the operation of different cylinders

Analysing Fig. 14, we can see that the concentration of $\mathrm{O}_{2}$ reaches its maximum values during the operation of the 1 st cylinder and the exhaust gas intake in the common exhaust pipe. We can see that the concentration of $\mathrm{O}_{2}$ is on average $16.2 \%$, whereas the concentration of $\mathrm{O}_{2}$ is below $2 \%$ during the operation of the 1st cylinder and the exhaust gas intake in the exhaust manifold immediately after the exhaust gases leave the cylinder and the operation of all the four cylinders and the exhaust gas intake in the common exhaust pipe. This is also explained by the impact of free oxygen from the neighbouring cylinders on the control result.

\section{OPERATIONAL TESTS}

As a result of the operational tests, we obtained comparative nomograms for determining the technical condition of the electromagnetic nozzles, the catalytic converter and the spark plugs of VAZ cars according to the results of analysing the exhaust gas composition. The maximum value of the upward or downward change in the registered parameter was taken for $100 \%$. Zero value is taken at the reference condition of the elements specified by the manufacturer. It is convenient to consider the relative values of the parameters in $\%$. The following parameters were controlled at the output: $\mathrm{CO}$ content, $\mathrm{CO}_{2}$ content, $\mathrm{CH}$ content, $\mathrm{O}_{2}$ content, and the ICE crankshaft speed $n$. These parameters are measured by different values, but it is very convenient to compare them in \% (Fig. 15).

We can see from Fig. 15 that the parameters $\mathrm{CH}$ and $\mathrm{O}_{2}$ take the maximum change. The concentration of $\mathrm{CH}$ increases significantly with an increase in the capacity of the electromagnetic nozzle. The concentration of $\mathrm{O}_{2}$, on the contrary, decreases significantly with an increase in the capacity of the electromagnetic nozzle.

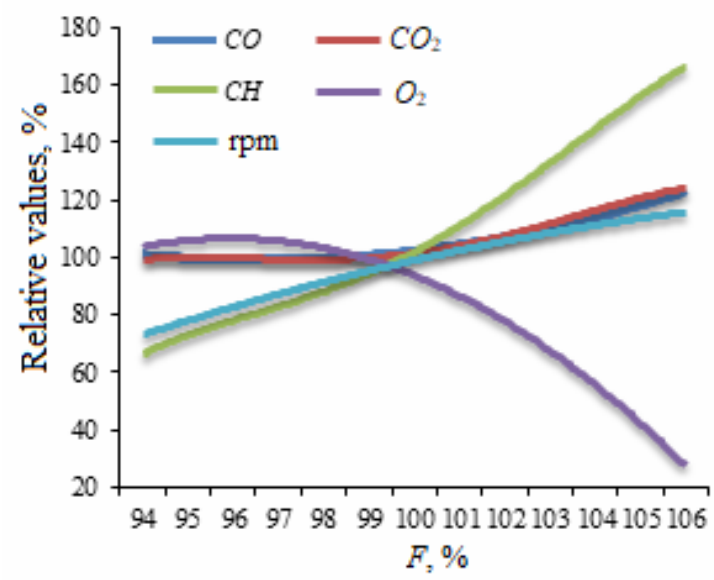

Figure 15. The complex dependence of the relative values of the controlled parameters of the content of $\mathrm{CO}, \mathrm{CO}_{2}, \mathrm{CH}$, $\mathrm{O}_{2}$, and the ICE crankshaft speed $n$ on the capacity of the electromagnetic nozzle $F$ (for VAZ ICE)

The ICE crankshaft speed increases almost linearly with an increase in the capacity of the electromagnetic nozzle. The parameters $\mathrm{CO}$ and $\mathrm{CO}_{2}$ begin to increase significantly with a change in $\mathrm{F}$ from 100 to $106 \%$, with an entry of the rich air-fuel mixture.

Let us consider the complex dependence of the relative values of the controlled parameters of the $\mathrm{CO}$ content, $\mathrm{CO}_{2}$ content, $\mathrm{CH}$ content, $\mathrm{O}_{2}$ content, and the ICE crankshaft speed $n$ on the spark plug gap $Z(\mathrm{~mm})$ (for VAZ ICE) (Fig. 16).

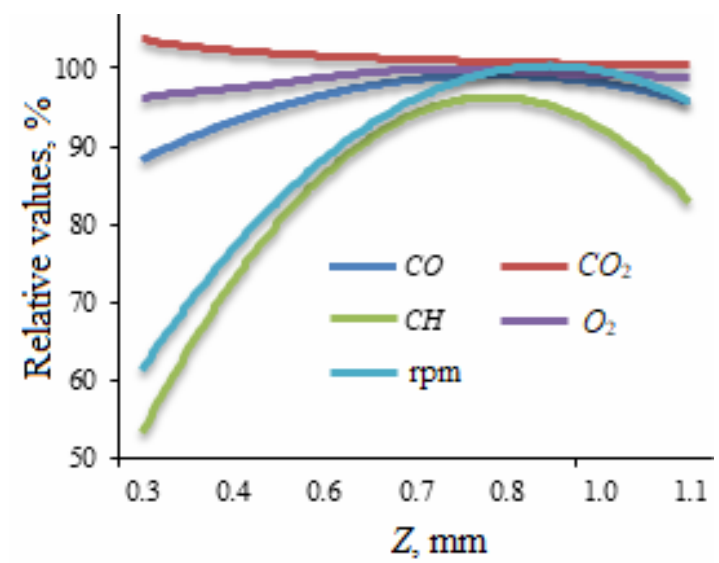

Figure 16. The complex dependence of the relative values of the controlled parameters of the content of $\mathrm{CO}, \mathrm{CO}_{2}, \mathrm{CH}$, $\mathrm{O}_{2}$, and the ICE crankshaft speed $n$ on the spark plug gap $Z$ (for VAZ ICE)

An analysis of Fig. 16 shows that the parameters $\mathrm{CH}$ and the ICE crankshaft speed reach the maximum changes. At the same time, the parameters $\mathrm{CH}$ and $\mathrm{n}$ sharply increase to $Z=0.8 \mathrm{~mm}$ with an increase in the spark plug gap.

The values of $\mathrm{CO}$ and $\mathrm{O}_{2}$ grow with an increase in $Z$, but at $Z=0.8 \mathrm{~mm}$, the growth slows down.

We should say that varying the spark plug gap did not show the expected result. This particularly concerns the placement of gaps less than $0.6 \mathrm{~mm}$. We observed a tendency that with an increase in the temperature of the 
exhaust manifold, the concentration of $\mathrm{CH}$ decreased markedly. The values of the concentration of $\mathrm{CH}$ presented in Fig. 16 also varied from 0 to $30-40 \mathrm{ppm}$. That is, these changes were too close to the error margin of the gas analyzer and the imposition of other external factors.

Let us consider the complex dependence of the relative values of the controlled parameters of the $\mathrm{CO}$ content, $\mathrm{CO}_{2}$ content, $\mathrm{CH}$ content, $\mathrm{O}_{2}$ content, and the ICE crankshaft speed $n$ on the equivalent resistance of the catalytic converter $R$ (mm) (for VAZ ICE) (Fig. 17).

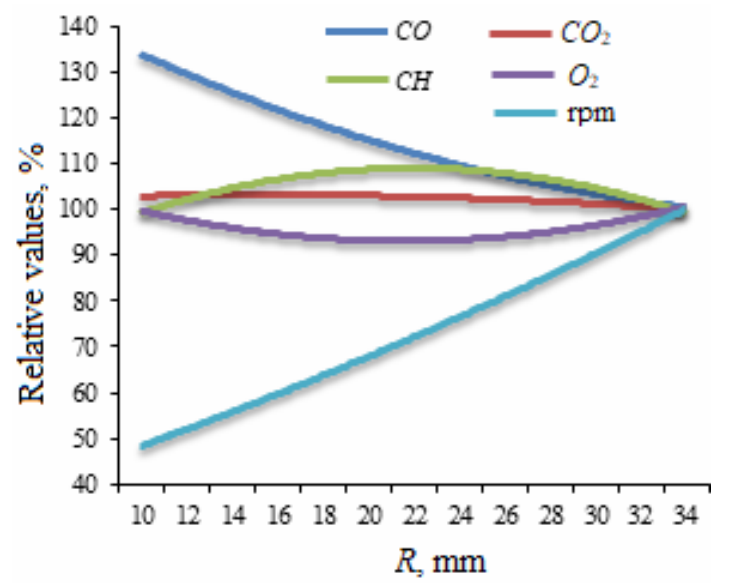

Figure 17. The complex dependence of the relative values of the controlled parameters of the content of $\mathrm{CO}, \mathrm{CO}_{2}, \mathrm{CH}$, $\mathrm{O}_{2}$, and the ICE crankshaft speed $n$ on the equivalent resistance of the catalytic converter $R(\mathrm{~mm})$ (for VAZ ICE)

An analysis of Fig. 17 shows that the parameters $C O$ and $\mathrm{n}$ change to the maximum extent. The concentration of $C O$ increases with an increase in the equivalent resistance of the catalytic converter. At the same time, the value of $n$, on the contrary, drops sharply with an increase in the equivalent resistance of the catalytic converter.

The parameters $\mathrm{CH}, \mathrm{CO}_{2}$ and $\mathrm{O}_{2}$ will not change so noticeably, but they have obvious maximums and minimums within $R=22 \mathrm{~mm}$.

\section{CONCLUSION}

The state analysis showed that the dominating number of failures falls at the ICE: the ignition system $-15-25 \%$, the power system - 30-44\%, the exhaust system - 10 $15 \%$. The creation and implementation of methods and tools for test diagnosing of the electromagnetic nozzle, the catalytic converter, and spark plugs allow us to get the annual savings of funds on one diagnostic station in the range of $699,700-855,200$ rubbles.

\section{ACKNOWLEDGMENT}

The work was supported by Act 211 Government of the Russian Federation, contract № 02.A03.21.

\section{REFERENCES}

[1] Makarova, I., Shepelev, V., Mukhametdinov, E., Pashkevich, A.: Changing the maintenance and repair system while expanding the connected vehicles fleet, in: Proceedings of the 6th International Conference on Vehicle Technology and Intelligent Transport Systems, 02-04.05.2020, Prague, pp. 622-633.

[2] Gabsalikhova, L. Makarova, I. Shepelev, V. Fatikhova, L. and Belyaev, E.: Connected vehicles fleet expanding problems, in Proceedings of the 6th International Conference on Vehicle Technology and Intelligent Transport Systems, 02-04.05.2020, Prague, pp. 642-650.

[3] Magaril, E.R., Magaril, R.Z., and Bamburov, V.G.: Specific features of combustion in gasoline-driven internal combustion engines, Combustion, Explosion, and Shock Waves, Vol. 50(1), pp. 7579. 2014.

[4] Czech, P. and Bąkowski H.: Diagnosing of car engine fuel injectors damage using DWT analysis and PNN neural networks, Transport Problems, Vol. 8, No. 3, pp. 85-91, 2013.

[5] Matskerle, Yu.: Modern economical car, Mashinostroenie, Moscow, 1987.

[6] Davletova, N.Kh.: Motor transport as a global source of air pollution, Modern high technologies, No. 4, pp. 90-98, 2005.

[7] Hambartsumyan, V.V., Nosov, V.B. and Tagasov, V.I.: Ecological safety of automobile transport, Publishing house «Nauchtekhlitizdat», Moscow, 1999.

[8] Nyberg, M.: Model-based diagnosis of an automotive engine using several types of fault models, IEEE Transactions on Control Systems Technology, Vol. 10(5), pp. 679-689, 2002.

[9] Gritsenko, A.V., Glemba, K.V., Larin, O.N., Shefer, L.A., Salimonenko, G.N., Karpenko, A.G. and Rudnev, V.V.: The study of the environmental parameters of gasoline ICE while simulating various loading modes, Ural transport, Vol. 3, No.58, pp. 58-63, 2018.

[10]Chelnokov, A.A. and Yushchenko, L. F.: Fundamentals of industrial ecology, Higher school, Minsk, 2001.

[11] Gritsenko, A.V., Glemba, K.V. and Vozmilov, A.G.: Improving the car environmental qualities by studying the engine load characteristics in the modes of injection rate off, Transportation Research Procedia, Vol. 36, pp. 237-244, 2018.

[12] Hsu, P., Lin, K. and Shen, L.: Diagnosis of multiple sensor and actuator failures in automotive engines, IEEE Transactions on Vehicular Technology, No.44(4), pp.779-789, 1995.

[13] Plaksin, A.M., Gritsenko, A.V., Glemba, K.V., Lukomsky, K.I. and Shepelev, V.D.: Test methods for diagnosing automobile internal combustion engine systems, YuUGAU, Chelyabinsk, 2016.

[14] Gritsenko, A.V., Zadorozhnaya, E.A. and Shepelev, V.D.: Diagnostics of friction bearings by oil pressure parameters during cycle-by-cycle loading, Tribology in Industry, Vol. 40. Iss. 2, pp. 300-310, 2018.

[15] Savchenko, O.F., Alt, V.V., Olshevsky, S.N. and Dobrolyubov, I.P.: Development of technical 
means for diagnosing tractor internal combustion engines according to the parameters of work processes. Proceedings of GOSNITI, Vol. 118, pp. 106-112, 2015.

[16] Shumilin, A.D., Lyandenbursky, V.V., Kapunova, M.K., Ivakhin, V.V. and Moiseev, I.S.: Expert system for monitoring the technical condition of automobiles, Scientific Review, No. 4, pp. 85-89, 2016.

[17] Ageev, E, Scherbakov, A., Ageev, A. and Kudryavtsev, A.: Technical endoscopy of car engines, Kursk, 2016.

[18] Ageev, E, Kudryavtsev, A., Sevostyanov, A.: Improving the quality of diagnostics of car engines, The World of Transport and Technological Machines, No. 3, pp. 24-27, 2011.

[19] Gritsenko, A.V., Shepelev, V.D. and Moor, A.D. A test method for individual control of the engine's ecological parameters, in Proceedings of the International Science and Technology Conference on Earth Science, 10-12.12.2019, Russky Island; 459 (4).

[20] Ageev, E., Altukhov, A., Scherbakov, A. and Novikov, A.: Informativeness increasing of internal combustion engines diagnosis due to technical endoscope, J. of Eng. and Applied Sciences, No. 12 (4), pp.1028-1030, 2017.

[21] Ageev, E, Kudryavtsev, A. and Sevostyanov, A.: An algorithm for diagnosing a cylinder-piston group using a technical endoscope, World of transport and technological machines, No.1, pp.116-122, 2012.

[22] Denisov, A. and Danilov, Yu.: Justification of a comprehensive assessment of the technical condition of ICE, Truck, No. 7, pp. 30-31, 2016.

[23] Wołczyński, Z., Komorska, I. and Borczuch, A.: Fault simulation of the sensors in gasoline engine control system, in: Proceedings of the Scientific Conference on Automotive Vehicles and Combustion Engines, 13-14.09.2018, Cracow, Paper 022042.

[24] Komorska, I., Woczyski, Z. and Borczuch, A.: Fault diagnostics in air intake system of combustion engine using virtual sensors, Diagnostyka, No.19(1), pp. 25-32, 2018.

[25] Eriksson, L. and Nielsen, L.: Ionization current interpretation for ignition control in internal combustion engines, Control Engineering Practice, Vol. 5., No 8, pp. 1107-1113, 1997.

[26] Makarova, I., Khabibullin, R., Belyaev, E. and Belyaev, A.: Improving the system of warranty service of trucks in foreign markets, Transport Problems, Vol. 10, No. 1, pp. 63-78, 2015.

[27] Gritsenko, A., Shepelev, V., Zadorozhnaya, E. and Shubenkova, K.: Test diagnostics of engine systems in passenger cars, FME Transactions, Vol. 48, No. 1, pp. 46-52, 2020.

[28] Scattolini, R., Siviero, C., Mazzucco, M., Ricci, S., Poggio, L. and Rossi, C.: Modelling and identification of an electromechanical internal combustion engine throttle body, Control Engineering Practice, Vol. 5, No 9, pp 1253-1259, 1997.

[29] Franchek, M. A., Buehler, P. J. and Makki, I.: Intake air path diagnostics for internal combustion engines, Journal of Dynamic Systems, Measurement and Control, Transactions of the ASME, No. 129(1), pp. 32-40, 2007.

[30] Wenzel, T. A., Burnham, K. J., Blundell, M. V. and Williams, R. A.: Kalman filter as a virtual sensor: Applied to automotive stability systems, Transactions of the Institute of Measurement \& Control, 2007, No. 29(2), pp. 95-115.

[31] Petrović, V. S., Janković, S. P., Tomić, M. V., Jovanović, Z. S. and Knežević, D. M.: The possibilities for measurement and characterization of diesel engine fine particles, A review. Thermal Science, No. 15(4), pp. 915-938, 2011.

[32] Petrović, V., Bracanović, Z., Grozdanić, B., Petrović, S., Sazhin, S. and Knežević, D.: The design of a full flow dilution tunnel with a critical flow venturi for the measurement of diesel engine particulate emission, FME Transactions, No.43(2), pp. 99-106, 2015.

[33] Vertey, M.L.: Justification of the method of acceleration of the engine with forced fuel injection and electric fuel supply control during the test diagnosis, Bulletin of Altai State Agrarian University, No 2 (124), pp. 112-116, 2015.

[34] Zhegalin, O.I., Kitrossky, N.A. and Panchishny, V.I.: Catalytic converters of transport engines. Mechanical Engineering, Moscow,1979.

[35] Plaksin, A., Gritsenko, A. and Glemba, K.: Experimental studies of cylinder group state during motoring, in: Proceedings of the 2nd International Conference on Industrial Engineering, 1920.05.2016, Chelyabinsk, pp. 1188-1191.

\section{КОНТРОЛА ЖИВОТНЕ СРЕДИНЕ И ИСПИТИВАҢЕ ДИНАМИКЕ КОНТРОЛЕ ИЗЛАЗНИХ ПАРАМЕТАРА МОТОРА}

\section{А. Гритсенко, В. Шепелев, Г. Салимоненко, Ј. Черкасов, П. Бујвол}

Контрола животне средине има кључну улогу у модерном транспорту приликом обликовања стратегије управљања техничким условима чворних места и система. Први корак у смањењу токсичности емисије издувних гасова представљало је увођење ЕУРО стандарда, почевши од стандарда ЕУРО 0 до стандарда ЕУРО 6. Заједно са увођењем ЕУРО стандарда системи издувних гасова су допуњени каталитичким конверторима који деактивирају већи део штетне емисије. Сензори кисеоника такође играју значајну улогу, јер се њиховим инсталирањем добија повратна информација. Тиме се глобална аутомобилска индустрија приближила могућности контроле излазних параметара мотора. Међутим, не 
постоји довољан број параметара, режима рада и додатних контролних уређаја за ову намену. У раду je приказан нови метод селективне контроле издувних гасова у сваком цилиндру. Праћени су следећи параметри: брзина брегасте осовине, потпуно и делимично искључивање цилиндара (циклус по циклус), $\mathrm{O}_{2}, \mathrm{CO}, \mathrm{CO}_{2}$ и $\mathrm{CH}$. Режим рада је обезбеђен бројем искључених завршених циклуса и брзином брегасте осовине. Контрола је изведена унутрашњим прилагођавањем довода горива под утицајем времена трајања убризгавања помоћу електромагнетне бризгаљке. Одређене су минималне вредности параметара токсичности издувних гасова за време трајања испитивања. Метод који обједињује режиме рада и параметре омогућава смањење токсичности издувних гасова и побољшава степен искоришћености и учинак возила. 